SB 983

I3 A4

Copy 1 


\section{0219284809}

Metal Edge, Inc. 2006 P.A.T. 


\section{ANNUAL STATEMENT}

OF THE

\section{Illinois State Entomologist}

\section{STATE HORTICULTURAL SOCIETY}

CONCERNING

Operations Under the Horticultural Inspection Act.

By S. A. FORBES,

5 State Entomologist.

Deeember 20, 1899. 
EY ToANSRTH

AUG 231915

-

$\therefore \vdots \vdots$ 


\title{
STATEMENT OF THE
}

\section{STATE ENTOMOLOGIST}

CONCERNING OPERATIONS UNDER THE HORTICULTURAL

INSPECTION ACT.

\author{
BY S. A. FORBES.
}

\section{THE WORKINGS OF THE SAN JOSE SCALE LAW.}

'The office of state entomologist of Illinois was established by law in $186 \%$, and charged with the duty of investigating the entomology of the state, and particularly of studying the history of the insects injurious to the products of the horticulturists and agriculturists of Illinois. The entomologist was also required to prepare a report of his researches and discoveries in entomology for publication by the state annually, this requirement being later changed to make the report a biennial one. Otherwise the duties of the office have remained without alteration until the passage of an emergency act by the last legis lature, approved April 11, 1899, by which the entomologist was required to "inspect, or to cause to be inspected by his duly appointed assistants, once each year all nurseries in the state of Illinois as to whether they are infested by dangerous insects or infected with contagious plant diseases, and if upon such inspection such nurseries appear to be free from such dangerous insects or diseases he shall, upon the payment of the expenses of inspection as certified by him, give to each owner of such nursery or nurseries a certificate to the facts, and shall file duplicate certificates with the director of the state agricultural experiment station and with the secretary of the State Horticultural Society, which certificates shall be at all times subject to public inspection." It is further made his duty to inspect, or to cause to be inspected, any property or place in the state which he shall have reason to suppose to be affected by dangerous insects or contagious plant diseases, on discovery of which he must give written notice to the owner or person in charge and direct him so to treat the infested property as to prevent the conveyance or spread of the injury to other 189. Reprinted from the Transactions of the Illinois State Horticultural Society for 
premises, this notice amounting to a quarantine of the premises to which it applies. In case the owner does not conform to this direction, the entomologist must cause the property or premises to be properly treated, and the owner is required to pay one-half the cost of treatment. An exception was made, however, of property infested by the San Jose scale before the year 1899 , which must be treated by the entomologist without charge to the owner.

The shipment of uncertified nursery stock into the state is checked by a provision of law requiring the transportation agent to hold such uncertified stock at the office of delivery until notice has been given to the state entomologist and a certificate of inspection issued by him.

The violation of any part of this law is made a misdemeanor punishable by a fine of not less than ten nor more than one hundred dollars, and it is made the duty of the state's attorney to prosecute.

The entomologist is further required to make a biennial report and financial statement to the governor, and an annual statement to the State Horticultural Society showing the Illinois nurseries inspected, the number and kinds of certificates issued, the location and ownership of the premises disinfected by him or his assistants, the kinds and amount of property destroyed under the act, and such other facts concerning the operations of his office under the act as the executive committee of the Horticultural Society may request. It is in pursuance of this last requirement that this paper has been prepared.

It will be seen that the operations for which the office is responsible on which report is to be made to this society are included under the two heads of nursery inspection, and the insecticide or fungicide treatment of infested or infected property.

\section{ANNUAL INSPECTION OF NURSERIES.}

Preliminary to the inspection of nurseries it was necessary that I should have a complete list of Illinois nurserymen, and this was secured, with very few deficiencies, (1) by comparing published trade lists of those engaged in the nursery business in Illinois, (2) by sending to nurserymen in every county where nurseries were known to occur a list of the names of nurserymen for that county with a request for additions and corrections, and (3) by careful inquiry by inspectors at county seats of counties visited by them and of nurserymen whose premises were inspected. Additional information was secured from postmasters in counties from which no nurseries were given in the published lists.

I have been somewhat embarrassed to determine just what should be called a nursery under the law, the dictionary definitions of the word being usually very comprehensive and sometimes indefinite. By the Standard dictionary a nursery is defined as "a place where trees, 
shrubs, flowering plants, etc., are raised for sale or transplanting," and by the Century dictionary as "a place where trees are raised from seeds or otherwise in order to be transplanted; a place where vegetables, flowering plants and trees are raised (as by budding or grafting), with a view to sale." Both these definitions might easily be made to include plantations of small fruits, greenhouses, truck gardens, and gardens of flowering plants. Being strongly of the opinion, however, that it was not the intention of the law that property of this kind should be subject to the annual inspection, $\bar{I}$ decided to apply the term in the sense in which it is commonly used in business; that is, to make a distinction between the nurseryman, the florist, and the vegetable gardener, while recognizing the fact, of course, that some nurserymen sell flowering plants and some florists sell nursery stock. In this sense a nursery may be defined as a place where trees, shrubs, and woody vines are grown for sale. This includes all fruits except those growing on herbaceous plants, as well as ornamental trees and shrubs.

For purposes of inspection the state was divided into four districts, one northern, one southern, and two central, in such a manner that each could be completely covered by a continuous trip, the principal lines of railroads largely determining the boundaries of the districts. To each of these divisions of the state an inspector was assigned early in July, with instructions to go from place to place by the shortest and most convenient lines of travel, not returning to the office until his district was fully inspected. I exercised great care in the selection of inspectors, since the law requires that they shall be competent scientific and practical entomologists, and gives to their acts done in pursuance of my instructions the same validity as to my own. It was particularly necessary that they should be known to me personally as thoroughly reliable men, and it was especially desirable that they should have due tact and discretion and a considerable experience of average human nature. I was fortunately able to provide for this work from my regular corps of assistants, all well known to me. Mr.E.C.Green was assigned to the northern district, Mr. R. W. Braucher to the north-central, Mr. F. M. McElfresh to the south-central, and Mr. H. O. Woodworth to southern and southeastern Illinois.

The regular work of inspection in the northern district was begun July 6 and finished September 14 ; that in the north-central was begun July 11 and finished September 15; and that in southern Illinois was begun July 6 and finished September 13. In the south-central division the inspection was begun July 26 , being delayed by some previous engagement of Mr. McElfresh, and was interrupted by his appointment September 4 as instructor in entomology to the Oregon Agricultural College. It was resumed in this district September 19 by Mr. Woodworth, after he had finished his own special work, and was completed 
October 9. Eight nurseries of which we had no knowledge at the time the regular trips were made were subsequently inspected on special trips. The total number of premises inspected to December 10 was two hundred and seventy-five. Eighteen of these proved, however, not to be nurseries, the owners asserting that their stock was not intended for sale, and by a change of ownership since inspection two of these nurseries have been merged as one. This leaves two hundred and fifty-six nurseries in the state, some scarcely worthy to be called by that name, but all coming, so far as my information goes, under the technical definition given. Seventy-seven of these nurseries are in those counties grouped by the State Horticultural Society as northern Illinois, seventy-eight in central Illinois, and one hundred and one in southern Illinois.

I append to this statement a list of all the nurseries inspected, arranged by counties alphabetically, giving the names and addresses of owners, and the dates of certificates where these have been issued. Two hundred and nine of the two hundred and fifty-six nurseries in the state are now covered by my certificate of inspection, leaving forty-seven without certificates. Only one of these forty-seven has been refused a certificate, and this a small lot belonging to a dealer and containing only left-over stock of preceding years. The remaining forty-six nurserymen have not as yet paid the expenses of inspection, without which I have no authority of law to issue a certificate. It is not to be assumed that all these forty-eight delinquents are evading the payment of the inspection expenses or transacting business in violation of the law. A small number are undoubtedly so doing, but I have reason to suppose that the greater part of them are delaying payment because they do no fall business, and consequently do not yet need the inspection certificate. Indeed, ten nurserymen have explained their delay of payment in this way, and twenty-nine other nurseries are described by my inspectors as so small and poor that most or all of them probably belong to the same class. Nineteen of the two hundred and nine nurseries finally certified-nearly ten per cent of the whole-were in such a condition that it was impossible to issue certificates of freedom from dangerous insects or plant diseases upon the face of the inspectors' reports, and in these nineteen cases the certificates were withheld until certain prescribed conditions had been fulfilled, or until satisfactory assurance was given that these requirements would be met.

Of the two hundred and ten certificates issued, two hundred and three were in identical form as follows: 


\section{OFFICE OF THE ILLINOIS STATE ENTOMOLOGIST.}

URBANa, ILL.,................ ises

THIS IS To CERTIFY that the growing nursery stock and prem-

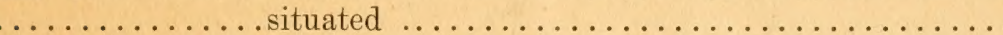
have been inspected according to the provisions of an Act to prevent the introduction and spread in Illinois of the San Jose scale and other dangerous insects and contagious diseases of fruits, approved and in force April 11, 1899, and that no indications have been found of the presence of the San Jose scale or other dangerous insect or plant disease.

This certificate is invalid after June $1, \ldots \ldots$.

\section{S. A. Forbes, State Entomologist.}

In seven cases the nurseries were in such condition as to require a limitation of the certificate, and two such forms of special certificates were issued. When certain kinds of stock in a nursery were condemned as unfit for the market, a certificate was issued covering by name only those kinds to the sale of which no objection was found. In a few cases the sale of nursery stock was prohibited until certain precautionary and insecticide measures were applied under the supervision of an agent of my office, and a certificate was then issued in the following form:

This is to certify that the nursery stock bearing this certificate and grown on the premises of ...................... situated at........................... been inspected according to the provisions of an Act to prevent the introduction and spread in Illinois of the San Jose scale and other dangerous insects and contagious diseases of fruits, approved and in force April 11, 1899, and that no indications have been found of the presence of the San Jose scale or other dangerous insects or plant disease.

This certificate is invalid after June 1, 1899.

In these cases the nurseryman agreed, in writing, that the certificate should be attached only to stock which had received the required treatment under the approval of an office assistant.

It is an evident requirement of the law that the expenses of nursery inspection should be paid by the owners of nurseries, and that the certificate should not issue until such payment is made. As this interpretation of the act was occasionally questioned by nurserymen, I asked the opinion of the attorney general, and was by him confirmed in the above understanding.

As the law does not prescribe any method of distributing costs of inspection trips to individuals whose premises are inspected, I was 
obliged to assess these expenses according to my best judgment of what was fair and just to all concerned. This was a delicate and embarrassing duty which I would gladly have avoided, and to which I gave careful personal attention. As the trips of my inspectors were not made separately for the purpose of inspecting individual nurseries, but were general trips in the course of which a large number were visited in succession, I was obliged to adopt some plan of division of the total expense of the common trip. After careful study of the workings of various possible plans, I finally adopted the following method:

I brought together every two weeks the inspection reports and bills of expense of each inspector, and the total cost of inspection for this period, including the salary of the inspector, was distributed among the nurseries concerned. This was done in such a manner that all should share equally the cost of transportation and some other general expenses, while the cost of subsistence and the pay of the inspector were divided among them in proportion to the time required for the inspection of each nursery.

Thus, if twenty nurseries were examined in these two weeks, each was charged with a twentieth part of the mere expense of traveling; and if the time spent in the inspection of a given nursery was, say, a fortieth of that spent in the inspection of all of them, then it was further charged with a fortieth of the salary and the cost of subsistence for the two weeks' period. In this way such expenses as had no relation to the size and condition of the nursery were divided equally; such as had some such relation were divided proportionally; and the total cost of all the trips was fully and exactly provided for.

This scheme worked upon the whole fairly and well, but had one minor disadvantage in the fact that it was practically impossible to make itemized statements to individual nurserymen, since the items would have included a complete exhibit of two weeks' expense of travel, but few of which it would have been possible for the individual nurseryman in any way to verify. Bills were, consequently rendered for the total sum due for each inspection, an explanation of the method of its determination being also sent if any question were raised, and the account was certified by me officially as required by law. The total cost of the inspection of the two hundred and ten nurseries* certified was $\$ 1,206.46$, an average of $\$ 5.74$ per nursery. The lowest charge for any inspection was 75 cents, against a small nursery near Champaign examined after the close of the general season by a special trip from my office, and the largest was $\$ 36.90$, paid by one of the principal nurseries of McLean county.

*Reduced to two hundred and nine by the purchase of one nursery by the owner of another after the annual inspection was made. 
The total amount of the forty-six unpaid charges for inspection is $\$ 209.02$, or $\$ 4.54$ per nursery. If we take away the ten highest of these charges, ranging from $\$ 5.43$ to $\$ 15 . \% 1$, then the average of the remaining thirty-six is but $\$ 3.72$. It is doubtless among the ten highest above mentioned that actual violations of the nursery inspection law this fall are mainly to be sought.

While discussing the finances of nursery inspection, I think it due to my office, upon which the disagreeable duty of making collections from nurserymen has been placed by law, to say that the pay of office salaries is in no way dependent upon these receipts, my inspectors being paid from the state appropriation so far as receipts from nurserymen fall short of expenditures on account of nursery inspection. Any assiduity as a collector which I may have exhibited or may in future exhibit is consequently to be attributed to a desire to preserve the appropriation made in this interest for the purpose to which it was intended that it should apply: that is, to the disinfection and insecticide treatment of orchards and other premises requiring that kind of attention, particularly those now infested by the San Jose scale.

Our main dependence for the protection of the horticulture of the state against the introduction and general spread of destructive insects and fungi is that section of the inspection law forbidding transportation companies to deliver uncertified stock. In order to insure a general knowledge of this law I distributed early in June, through the state railroad and warehouse commission, copies of the sections of the law covering this point to all the railroads running in or through the state, and to all express companies doing business in Illinois. I am unable to say how generally the law has been observed by these transportation companies. Only three cases of violation of it have come to my knowledge. One of them was in northern Illinois, where a Wisconsin nurseryman was prosecuted for distributing uncertified nursery stock, plead guilty, and paid the minimum fine. The railway agent who released this stock without certificate was of course also guilty under the law, but plead ignorance of its provisions. In two other cases packages of uncertified nursery stock were noticed in transit by rail by correspondents in southern Illinois. The receipt of uncertified nursery stock by railway agents has been three times reported to my office, all by one railroad having a comparatively short line in Illinois. A single case has also been reported by an express company, and this from my home office in Champaign. I have twice had an assistant in Chicago, who was there on other business, make a tour of express and railway freight offices during the fall shipping season, but nothing illegal was observed. 


\section{INSECTICIDE TREATMENT OF ORCHARDS.}

As soon after the approval of the law as practicable field work was begun from my office for the arrest of the spread of the San Jose scale in those parts of the state where it was likely to do most injury. The experience of the two preceding years with insecticide sprays, and published reports of experiments elsewhere with the fumigation method for the San Jose scale had led me to conclude that fumigation with hydrocyanic acid gas is the only method now known which gives any reasonable promise of the obliteration of the scale in any locality where it has become abundant or where it has spread beyond the point of its original introduction. I consequently decided to introduce this method in our own field operations. As this required, however, a large and expensive equipment of canvas tents for the enclosure of trees, together with some experience in the management of the apparatus and the application of the gas which my office force had never had, and as, further, the gas treatment can only be applied in the open air to the best advantage during the winter season, especially if extermination of the scale is the end in view, I decided to put a spraying party into the field last spring in the Sparta district, where the scale was most abundant and widespread, and was therefore most jikely to extend its area rapidly.

This party, in charge of Mr. R. W. Braucher, was instructed to spray such premises as required immediate treatment as a precaution against serious increase of injury or extension of the scale to adjacent property, the object of this preliminary procedure being not so much to exterminate the scale even locally as to arrest the extension of the injury temporarily until such time as the most thoroughgoing possible measures of extermination could be organized. Mr. Braucher was instructed, in order to facilitate the thorough application of the spray-extremely difficult at best when the trees are in leaf-to have infested trees cut back as freely as could be done without injury to the tree, and to have any property completely destroyed which was so badly infested by the San Jose scale as to be entirely worthless. He was instructed to bear in mind the fact that he was dealing in an official way with the property of the private citizen, and that he should use the ritmost tact and discretion, especially where the safety of other property demanded the destruction of that infested. In any case of serious disagreement between himself and the owner he was to refrain from immediate action, if this could be done without prejudice to the public interest, and to report the facts and his proposed procedure to my office.

Mr. Braucher's operations in the Sparta neighborhood began April 27 and continued until May 16, when he was assigned to other service. During this time he sprayed the infested orchards of the following owners living near Sparta, in Randolph county: J. M. 
Temple, S. A. Blair, J. W. Robinson, Mrs. J. B. Hayer, Bert Hayer, Jefferson Porch, James Wood, Jr., and Jantes Wrood, S'r. He destroyed as worthless the following fruit stock: It IIr. 'T'emple's, 267 peach-trees; at Mr. Robinson's, 126 peach-trees, 3 apple-trees, and 6 currant-bushes; at Mrs. Hayer's, 3 apple-trees; at Mr. Porch's, 22 peach-trees and 1 apple-tree; at James Wood's, Jr., 52 peach-trees and 2 apple-trees; and at James Wood's, Sr., $2 t$ peach-trees and 2 apple-trees. Fourteen hundred feet of osage orange hedge belonging to Messrs. Homer and Bert Hayer were also destroyed, partly by grubbing out and partly by burning with the aid of kerosene. The total property destroyed as worthless from San Jose scale injury thus consisted of 491 peach-trees, 11 apple-trees, 6 currant-bushes, and something over a quarter of a mile of osage orange hedge.

In order to make a begimning of fumigation work a suitable equipment of tents was provided for preliminary operations, and C. $1 \mathrm{~W}$. Woodworth, professor of entomology in the University of California, a former graduate of the Lniversity of Illinois, was engaged, for his traveling expenses, merely, to come to ('hampaign and to take charge of the fumigation work until our nom force should be competent to manage it independently. Mr. Woodworth was selected for this service because I knew that he had made a special study of fumigation operations in California and had published an elaborate bulletin upon the subject as one of the series of the California experiment station. A beginning was made June 5, in an infested lot in Monticello, Piatt "ounty. Prof. C. IV. Woodworth was in charge of the party, three of my assistants going over with him from Urbana, and two laborers being hired at Monticello. At this time of the year it was necessary to do the work at night, since exposure of foliage to the sun just after fumigation is likely to result in the scorching of the leaves. The miscellaneous vegetation upon one tow $n$ lot was treated here with the exeeption of two or three trees ton large for the tents. Other deficiencies of the apparatus laving been made manifest, work at this town was suspended until they could be made good, but by that time the season for nursery inspection had arrived. and fumigation was suspended to be taken up after the inspection season was past.

By the fifteenth of October foliage was so far fallen from the fruit-trees in southern Illinois that they could with safety be fumigated by day, and a party was consequently put into the field under the charge of $\mathrm{Mr}$. E. (. Green. with instructions to undertake the systematic fumigation of infested premises. Mr. R. Wr. Braucher was attached to the party as an inspector, with instructions to report to Mr. Green the exact distribution of the scale at Snarta. The work was continued at Sparta and its vicinity, extending to the town of Honston. reven miles awar, until December 16 . At this time it har become evident from the number of additional infested premises discovered in this region by $\mathrm{Mr}$. Brancher's inspections, and the general dis- 
cribution of the scale in this district on hedges and other roadside vegetation, that the complete extermination of the San Jose scale in Randolph county was an enterprise quite beyoud our powers with the resources at my disposal, even if all the appropriation made by the legislature for this general purpose were expended in this one locality. A change of program was consequently necessary, and fumigation operations were transferred to other points where there was at least a fair chance of accomplishing the local obliteration of the scale.

I have selected first those points where the presence of this insect threatens important fruit-growing districts certain to be seriously injured in time if an effective check is not put upon the spread of this pest. The first of these points fixed upon was Richview, in Washington county, and the fumigation party is now at work at that place.

The Sparta district in the meantime has not been wholly abandoned, but a spraying party has been organized to continue insecticide work with whale-oil soap, with a view to bringing the outbreak of the San Jose scale at that point completely under the control of the community, and to give to individual fruit growers ample instruction and demonstration in respect to the insecticide methods and machinery. which they must henceforth use if they wish to protect themselves against continuous injury by this insect.

Mr. Green has thus far fumigated trees and shrubs upon premises in Ràndolph county owned as follows: John Robinson, Alvin Blair, J. К. Blair,vifrester Brown,J. F. Blair,John Davison, MLr.J II. Moreland, James Jhavison, ('larles Lott, Mrs. .J. B. Taver, Bert Haver, Jefferson l'oreh, ITillam Wilsom, 'T. H. Wilson, James Trond. and Mrs. 'T. Brown. No property has been destroyed by him, although a considerable number of trees of various kinds have been pointed out to the owners of these premises as substantially worthless, and in most cases these will be removed and destroyed by the owners themselves.

In conclusion, I think that I may say that the new law is working, on the whole, fairly and smoothly and to the decided advantage of horticulture in this state. It might, perhaps, be improved by a few minor amendments, but upon that point I shall be better ahle to express myself positively after another year's experience of its adminstration. 'That it embodies a sound and valuable principle, and that it deserves in general the strong and unflinching support of nursermen and hortioulturists alike I have myedf no longer any roubt. It is to be hoped that it will be unnecessary to call upon the courts for its enforcement upon the small number of nurserymen who have thus far evaded its requirements. It seems likely that when the fact is known that nearly all Illinois nurserymen are obeying it without objection the remaining few will fall into line.

December 20, 1899. 

0021928480

Metal Edge, Inc. 2006 P.A.T. 


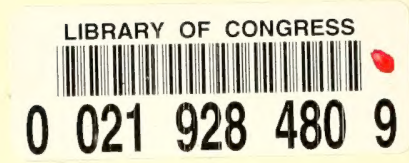

